\title{
Visualization of Narrow Rivers within Forested Areas Using JERS-1 SAR Images of the Amazon River Basin
}

\author{
アマゾン河流域の JERS-1 SAR 画像を用いた \\ 森林内の細い河川の可視化
}

\author{
Takako SAKURAI-AMANO*, Mikio TAKAGI**, \\ Susumu OGAWA***, Kyoichiro KATABIRA**** \\ 桜井 貴子・高木 幹雄・小川進・帷子京市郎
}

\begin{abstract}
We used strong isolated double-bounce reflections that appear along forest-water boundaries in JERS -1 SAR images of the Amazon River basin to represent small, narrow rivers that appear indistinct in the original images as bright lines in processed images reduced to $1 / 256$ size. Since the brightness seemed to correlate with the width/water level at the point of the stream, we examined seasonal changes in the brightness of several catchment areas along the Madeira River between 1993 and 1997 and found that the total brightness of a tributary system correlated to the length of its main tributary, a hydrological parameter that can be used to calculate discharge. A mosaic of such images can be used as a quick-look map of streams and flows in remote and often dangerous tropical forests. We then explored possibilities for estimating discharge from SAR data.
\end{abstract}

和文概要：アマゾン河流域の JERS-1 SAR 画像の森 林と水との境界に沿って現れる孤立した強い 2 回反射

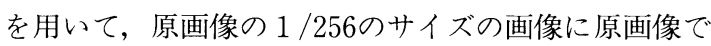
ははっきりしなかった小河川を明るい線として表し た。この画像では広い水面は暗い領域として実サイズ で表現される。この明るさが川の各地点の幅/水位に関 係しているように見えたので，1993年から1997年の データを用いて, Madeira 河流域のいくつかの小支流 域の川の明るさの季節変化を調べたところ，その明る さの総和は, 流出量を求めるのに使われる水文学的パ ラメータの一つである支流域の主流の長さに比例して いることが分かった。したがって，これらの画像のモ ザイクは，小さなサイズで広大な領域をカバーできる ので, 流路の変化しやすい人里離れた熱帯雨林地域の 小河川とその水量分布のクイックルック画像として実 用的な価值があると考之る。画像からの流出量推定の 可能性についても言及した。

* RS データ・アナリシス：RS Data Analysis

** 芝浦工業大学: Shibaura Institute of Technology

*** 立正大学：Rissho Univ., ****東京大学：Univ. of Tokyo

「写真測量とリモートセンシング」VOL. 44，NO. 5， 2005

$-64-$

\section{Introduction}

Satellite-based regular monitoring of spatial distribution of streams and amount of flow over tropical forests provides important information to preserve their fragile ecosystems because those forests tend to be extensive, remote, uninhabited, and often dangerous. L-band space-borne Synthetic Aperture Radars (SAR) provide one of the best options for observing the water surfaces in such areas because they are not adversely affected by the frequent cloud-cover (Ulaby et al., 1986) that characterize such areas.

Although many studies have been conducted with regard to L-band SAR detection of large flooded areas in natural forests (Krohn et al., 1983 ; Obmsby and Blanchard, 1985 ; Inhoff et al., 1987 ; Hess et al., 1990 ; Hess et al., 1995 ; Rosenqvist and Birkett, 2002 ; Rosenqvist et al., 2002), studies have not been sufficient with regard to the gradual increases of water in small rivers that eventually cause the 
floods. One of the reasons for this lack of study lies in the difficulty of detecting narrow rivers from SAR images.

In a previous paper (Sakurai-Amano et al., 2004), we noted that the appearances of water surfaces change as their widths change. Briefly, wide rivers appear as long, dark objects, but as they become narrower, they turn into continuous dark lines, and then into a series of dark linear blobs. The blobs become lighter as the river becomes even narrower and they eventually dissolve into the background. Along dark objects, we observe intermittently a series of very bright targets. These targets represent double-bounce reflections between water surfaces and tree trunks and/or large branches. Similar reflections are observed in inundated forests. The reflections can be used to distinguish dry areas from inundated areas because the intensities of such reflections are correlated with the dielectric constant of under-canopy ground (Richards et al., 1987a ; Richards et al., 1987b). We combined both the darkness of the water surfaces and the average intensities of the strong reflections to determine the amount of water flowing in narrow rivers.

This paper describes a method for emphasizing double-bounce reflections along forest-water boundaries to visually represent narrow rivers as bright lines in a much-reduced image. We showed that the brightness of those rivers is correlated with the amount of flow. In discussion, we correlated the total brightness of such rivers to their mainstream lengths, a hydrological parameter that can be used to calculate discharge. We also discussed the possibility of estimating discharge from those data briefly.

\section{Methodology}

The algorithm for detecting narrow rivers consists of speckle noise reduction, taking moving sums of absolute differences and moving averages, and size reduction.

\section{(1) Speckle noise reduction}

After resampling the original JERS-1 SAR images and reducing them to half in each dimension, we applied speckle reduction filters using a $5 \times 5$ square template. We used both the SFP filter and the Enhanced SFP (eSFP) filter (Sakurai-Amano and Iisaka, 1999 ; Sakurai-Amano et al., 2004) described as follows :

$x_{c}= \begin{cases}\frac{\sum_{k=-m}^{m} \sum_{l=-n}^{n} w_{k l} z_{k l}}{\sum_{k=-m}^{m} \sum_{l=-n}^{n} w_{k l}} & \text { if } z_{c}<a \\ z_{c} & \text { otherwise }\end{cases}$

where

$w_{k l}= \begin{cases}1 & \text { if } z_{k l}<a \text { and }\left|z_{c}-z_{k l}\right|<2 \sigma_{v} \bar{z}_{c} \\ 0 & \text { otherwise }\end{cases}$

$a=\left\{\begin{array}{l}\text { constant value } 65535 \text { for SFP filter } \\ \text { user specified value for eSFP filter }\end{array}\right.$

Here $x_{c}, z_{c}, z_{k l}, \bar{z}_{c}$, and $a$ are respectively the estimate of the center pixel, the value of the center pixel, the value of the window pixel at $(\mathrm{k}, 1)$, the average pixel value of the window pixels excluding pixels $z_{k l} \geq a$, and a user specified threshold value ${ }^{1}$. $\sigma_{v}$ is the standard deviation of multiplicative speckle noise.

Although the SFP filter is very good at smoothening the background and preserving isolated strong targets along rivers, it is not very good at preserving very small dark objects. To preserve the tiny dark blobs along rivers, dark SFP filtered pixel values $\left(v_{s}(i)<\right.$,$k for k \leq a$ where $k$ : user specifed value) are replaced with darker eSFP filtered pixel values $v_{e}(i, j)$.

\section{(2) Moving sum of absolute differences}

The moving sum of absolute differences between a central pixel and its surrounding pixels was calculated using a $5 \times 5$ square template to enhance isolated very bright point-like objects and to suppress

${ }^{1} a=65535$ for the SFP filter means $a$ is set to the maximum value for 2 byte data. 
bright area-like objects, e.g., inundated forests.

\section{(3) Moving average}

The moving box average was then calculated using a $9 \times 9$ square template to expand the enhanced isolated bright targets along rivers so that they overlap one another.

\section{(4) Reduction of image size}

The image was re-sampled and reduced in size to $1 / 8$ in both dimensions. The original $6400 \times 6000^{-}$ pixel image was thus reduced to a $400 \times 375$-pixel image and the enlarged bright target areas along rivers became bright lines.

\section{Data}

We used level 2.1 4-look JERS-1 SAR images (C) METI/JAXA) for paths 415 and 416 and rows 301 to 320. The area covers the Amazon River basin from more than $300 \mathrm{~km}$ north of Manaus to Rondonia. Pixel spacing is $12.5 \mathrm{~m}$. The width of rivers were estimated using JERS-1 VNIR images (CMETI/

Table 1. Daily discharge and average daily discharge in the corresponding month at Manicore Station on SAR observation date. (unit: $\mathrm{m}^{3} / \mathrm{s}$ )

\begin{tabular}{|r|r|r|r|r|r|}
\hline \multicolumn{3}{|c|}{ Path $=415$} & \multicolumn{3}{c|}{ Path $=416$} \\
\hline Obs. date & Daily & Ave & Obs. date & Daily & Ave. \\
\hline $02 / 10 / 93$ & 9532 & 9430 & $10 / 04 / 93$ & 52235 & 52535 \\
\hline $11 / 02 / 94$ & 42420 & 43165 & $03 / 10 / 93$ & 9279 & 9430 \\
\hline $06 / 08 / 94$ & 9463 & 12592 & $11 / 05 / 94$ & 45599 & 42974 \\
\hline $20 / 10 / 95$ & 4636 & 4823 & $07 / 08 / 94$ & 13181 & 12592 \\
\hline $13 / 04 / 96$ & 45520 & 45376 & $21 / 10 / 95$ & 4597 & 4823 \\
\hline $27 / 05 / 96$ & 32916 & 39386 & $02 / 05 / 96$ & 32302 & 39386 \\
\hline $10 / 07 / 96$ & 14510 & 13474 & $24 / 08 / 96$ & 5820 & 7007 \\
\hline $23 / 08 / 96$ & 5907 & 7007 & $01 / 04 / 97$ & 53578 & 55699 \\
\hline $06 / 10 / 96$ & 4109 & 5314 & $15 / 05 / 97$ & 52788 & 51764 \\
\hline $15 / 02 / 97$ & 39497 & 39433 & $28 / 06 / 97$ & 32072 & 38473 \\
\hline $31 / 03 / 97$ & 53301 & 48992 & $11 / 08 / 97$ & 11654 & 11115 \\
\hline $14 / 05 / 97$ & 53064 & 51764 & & & \\
\hline $10 / 08 / 97$ & 11941 & 11115 & & & \\
\hline
\end{tabular}

(from http://hidroweb.ana.gov.br/HidroWeb/)
JAXA) of the same area observed on August 6 and 7, 1994, one week later dates of JERS-1 SAR observation. We found we were visually able to detect narrow rivers down to roughly $20 \mathrm{~m}$ wide. Discharge data for the Madeira River observed at Manicore were obtained from http://hidroweb.ana.gov.br/ HidroWeb/. Table 1 shows the daily discharge on the SAR observation dates as well as the average daily discharge for the corresponding month measured at Manicore station.

\section{Results}

Fig. 1(a) $\sim$ (c) show respectively the original SAR image, the corresponding speckle-reduced images, and the visualized rivers. Fig. 1(d) is the corresponding near-infrared image of JERS-1 VNIR data observed one week later for comparison. Parameters $a$ and $k$ for speckle reduction described in section 2.1 were set to the values of $6000^{2}$ and 5950 respectively.

Fig. 2 shows a mosaic of visualized river images

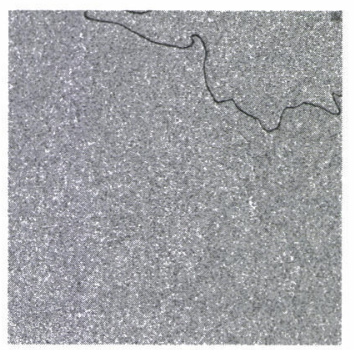

(a)

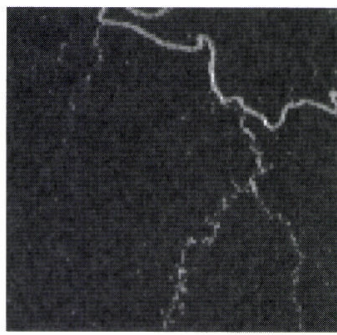

(c)

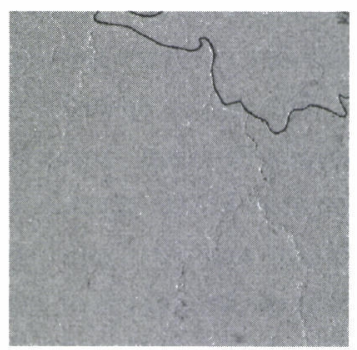

(b)

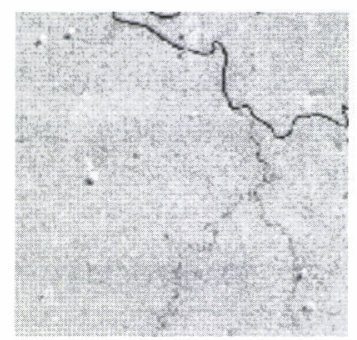

(d)
Fig. 1. Small pieces of JERS-1 SAR image from scene 416-313 observed in August 1996. (a) Original SAR image, (b) speckle-reduced image, (c) this method, and (d) near-infrared image of JERS-1 VNIR data. 


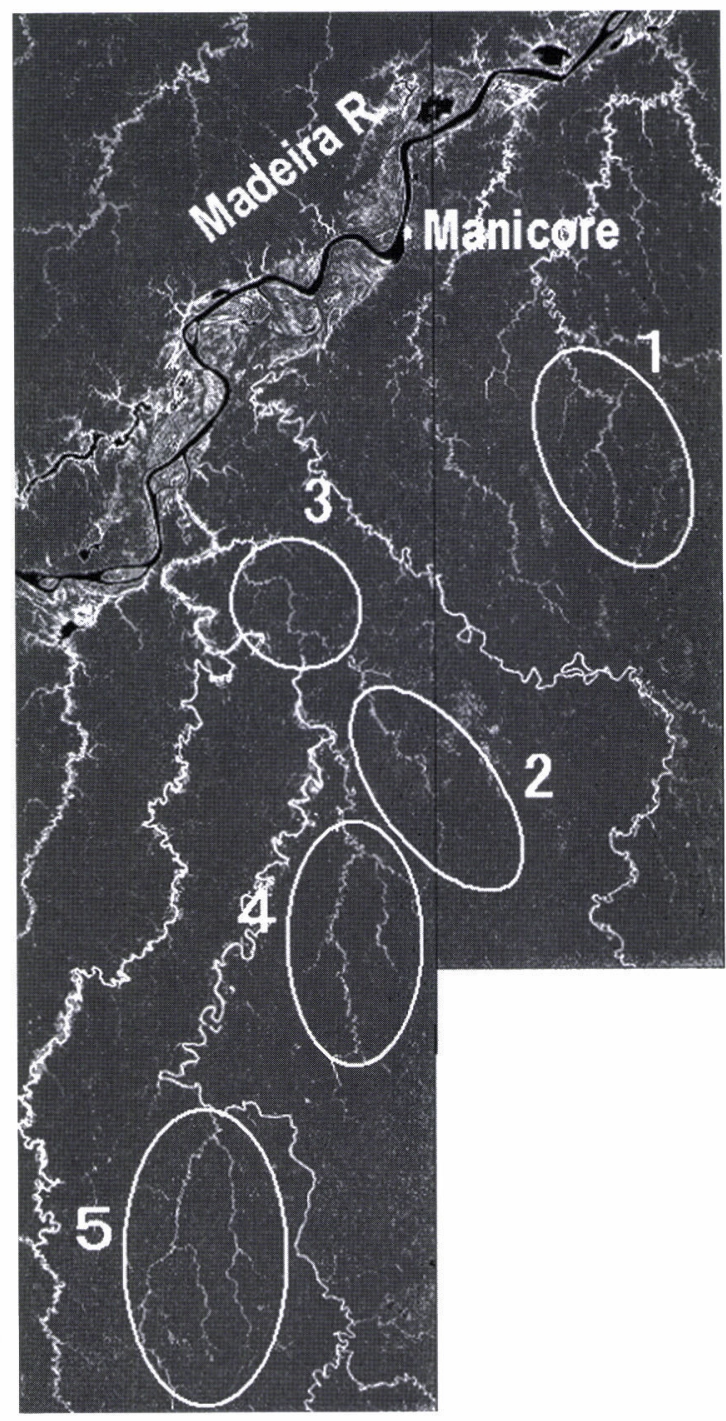

Fig. 2. The Madeira River and its tributaries in a mosaic of path -415 and -416 scenes observed in May 1996 (intensity enhanced images). Tributaries 1 to 5 correspond to tributaries " $415-311$ ", " 415 -312", "416-311", “416-312", and "416$313^{\prime \prime}$ in Fig. 4 and 5.

within scenes in paths 415 and 416 containing the Madeira River and its tributaries. This method shows large water surfaces such as the Madeira River and lakes larger than resolution pixel $(200 \mathrm{~m} \times$

${ }^{2} a=6000$ means $a$ is set to 6000 , a round number slightly higher than the highest pixel values of dark areas that are supposed to be water areas including water mixel areas. The average pixel value of dry forests was around $7700-7800$.
$200 \mathrm{~m}$ ) as dark objects in real size with bright lines at water-forest boundaries. Narrow rivers with widths less than resolution size $(200 \mathrm{~m})$ appear as bright lines $^{3}$. The widths of rivers appear correlated with their brightness in that brightness increases slightly from headwater to confluence.

The brightness of a stream also seems correlated to its water level, as it appears brighter in highwater seasons than in low-water seasons. Fig. 3 shows seasonal changes in the brightness of a small tributary system observed between 1993 and 1997. The length and the number of branches are at their maxima in high-water April and May and minima in low-water August and October. Although the coverage and frequency of observations by JERS-1 missions in other tropical forest areas such as the Congo Basin, New Guinea, and Borneo were not sufficient to allow detailed analysis, our preliminary studies showed similar patterns in the appearances of streams, i.e., bright in high-water seasons and dim in low ${ }^{-}$water seasons.

\section{5 . Discussion}

As shown above, the brightness of a stream seems to be correlated to both its width and its water level or volume. Let us consider whether the visualized river images can be used as a quick-look map of water distribution in those streams.

\subsection{Seasonal relationship between total brightness and mainstream length from SAR data}

Total brightness $B_{i}$ was defined as the sum of pixel values of the bright streams within a catchment area :

$B_{i}=\sum_{\text {stream-pixels }}\left(z_{i j}-F\right)$

where $z_{i j}$ is the pixel value of stream pixels and $F$

${ }^{3} \mathrm{We}$ checked several rivers with widths between $200 \mathrm{~m}$ and $300 \mathrm{~m}$ and found that a river about $250 \mathrm{~m}$ wide was the widest river we recognized as a single bright line. Note that water boundaries did not appear bright when the rivers did not flow through forested areas. 


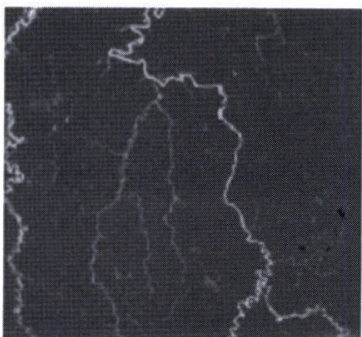

$10 / 04 / 93$

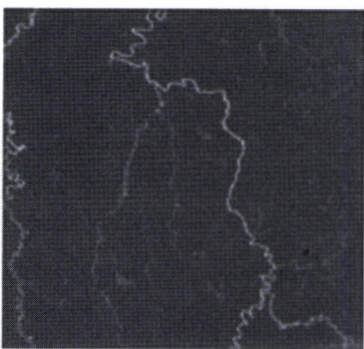

$21 / 10 / 95$

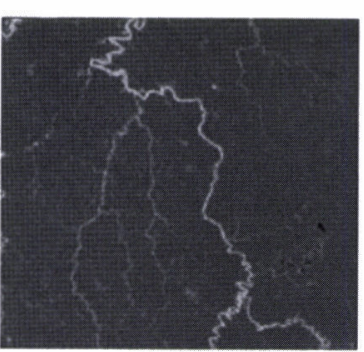

$1506 / 97$

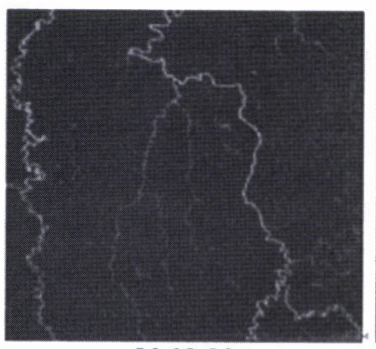

$03 / 10 / 93$

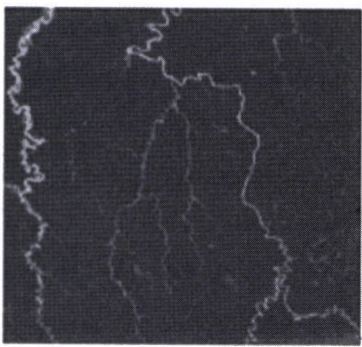

$28 / 05 / 96$

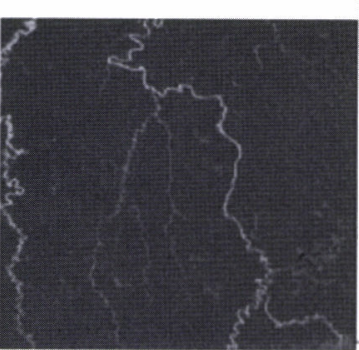

$28 / 06 / 97$

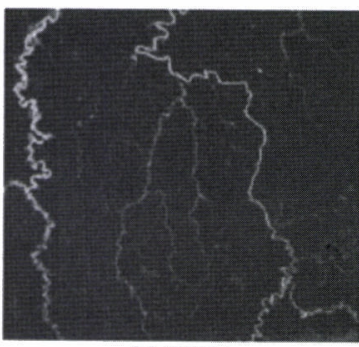

$11 / 05 / 94$

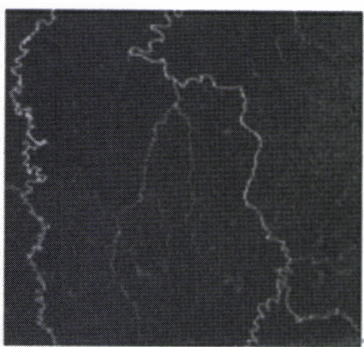

$24 / 08 / 96$

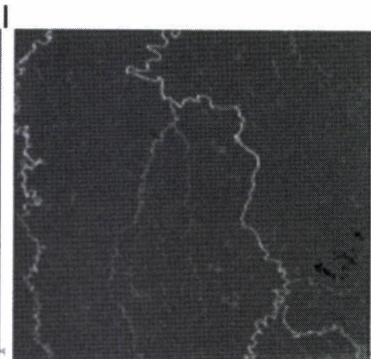

$11 / 08 / 97$

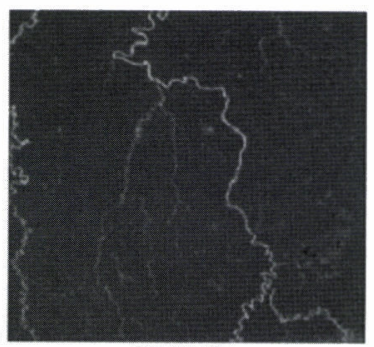

$07 / 08 / 94$

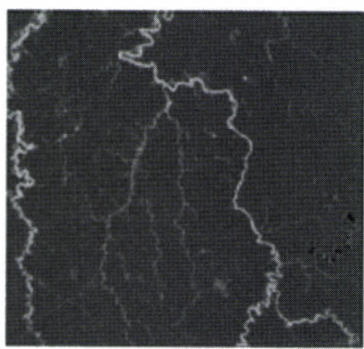

$01 / 04 / 97$

Fig. 3. Seasonal changes in the brightness of a small tributary system at the center of Scene D416-313 (tributary 5 in Fig. 2) between 1993 and 1997.

is the average pixel value of dry forests ${ }^{4}$. The bright stream pixels in a catchment area are derived as follows: (1) Extract a minimum rectangular area that encloses the catchment area to be analyzed ; (2) extract objects brighter than threshold value $T h$ $\left(T h=90,95\right.$, or 100 in this study $\left.{ }^{5}\right)$; (3) connect closely lined-up bright blobs using a morphological closing operation with a $5 \times 5$ circular template and select line-like blobs longer than 10 pixels; and (4) select the main stream and all connected streams.

${ }^{4}$ We used $F=60$, a value at the histogram peak of average dry-season forests.

${ }^{5}$ Objects brighter than $T h=90,95$, and 100 correspond to streams wider than about $20-30 \mathrm{~m}, 40 \mathrm{~m}$, and $50 \mathrm{~m}$. The value 90 is slightly higher than the average pixel value of inundated forests in the study.
Applying a skeltoning operation to the stream pixels, trimming all branches, and calculating the number of pixels then obtained mainstream length $L_{i}$ of a tributary system.

Fig. 4 plots the seasonal relationship between mainstream length $L_{i}(t)$ and total brightness $B_{i}(t)$ for five catchment areas indicated in Fig. 2. Note that high $L_{i}(t)$ and $B_{i}(t)$ values correspond to high -water seasons and low values to low-water seasons. These graphs show that (1) mainstream length in any catchment area increases in proportion to the total brightness at any threshold level, and (2) the gradients are roughly constant at all threshold levels.

Thus the total brightness of any tributary system appears to be proportional to its mainstream length, 

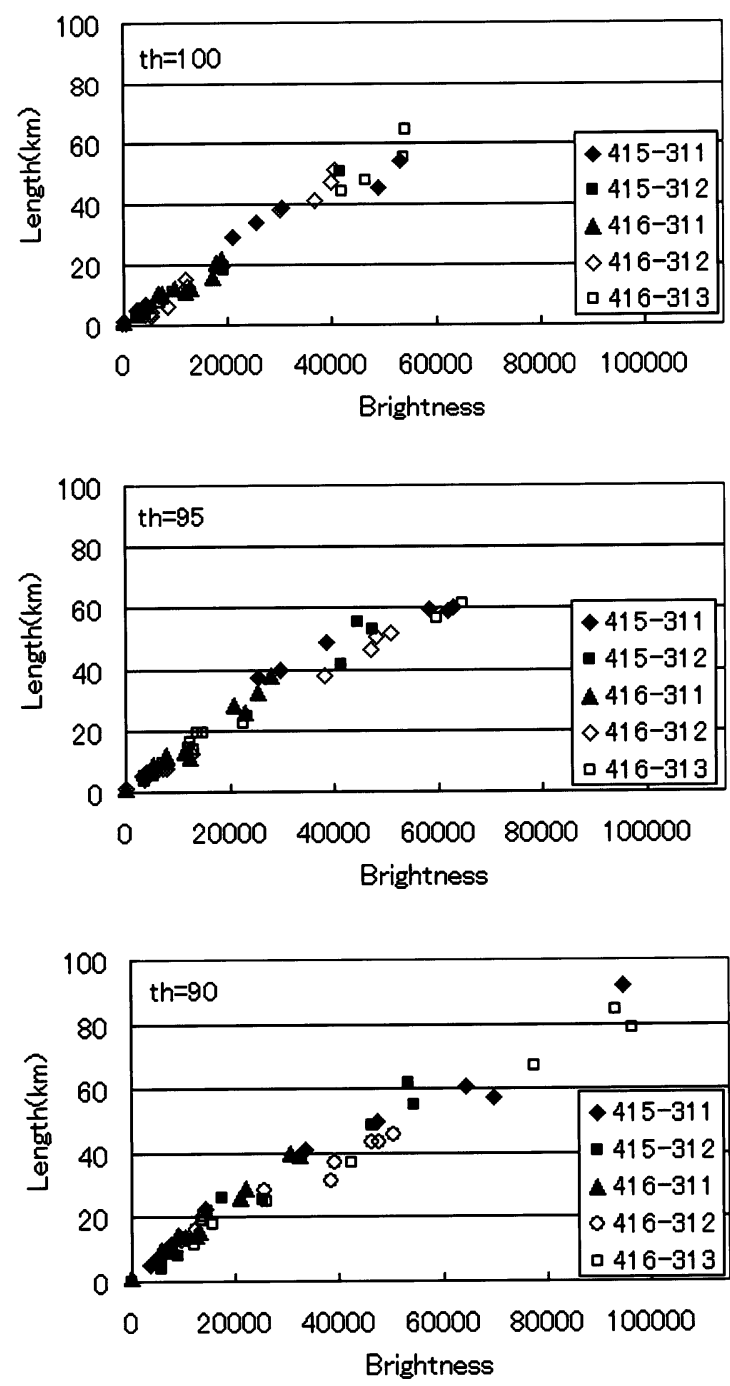

Fig. 4. Seasonal relationship between total brightness and mainstream length of several small tributaries at each threshold level.

a hydrological parameter that can be used to calculate discharge, and the brightness of each point can be regarded as a function of the amount of water there. The observation made in Section 4 that brightness correlates with the width and amount of water in a stream is thus confirmed.

\subsection{Estimating discharge from SAR data}

We tried inferring discharge in small tributaries from the catchment area sizes of the main streams, which in turn were derived from SAR observations of their length.

(1) Hydrological equations relating mainstream length, catchment area, and discharge

According to Hack's rule (Hack, 1957; Takahashi, 1980) the mainstream length $L$ of a tributary system is described as a function of catchment area A :

$L=a A^{0.6}$

where $a$ is an empirical constant. Discharge is described as a function of area $A$ :

$Q=j A^{m}$

where $j$ and $m$ are empirical constants. Hack obtained a figure of $m=1$ from his experiments with the Potomac River.

(2) Relationship between catchment area size and discharge of small tributaries

Using these two equations, it becomes theoretically possible to determine discharge $Q$ for any tributary system for any particular date of observation $t$. Specifically, given SAR-derived data for the length $L$ of a particular stream, Eq. (5) allows us to determine its catchment area size $A$, and this data in turn allows us through the use of Eq. (6) to determine its discharge $Q$.

We assumed that the empirical constant $a$ in Eq. (5) for small tributary systems is the same as that for the Madeira River ${ }^{6}$. We obtained $a=1.51$ for the Madeira River (using figures of $L=3,200 \mathrm{~km}$ and $A=1,380,000 \mathrm{~km}^{2}$ ), noting that the length and catchment area size of the Madeira River remained roughly constant; seasonal fluctuations in the length of the Madeira River fell within $100 \mathrm{~km}$ or about $3 \%$ of total river length, hence we felt that effects on calculations were negligible.

${ }^{6}$ In the following discussion, we assumed that all small tributaries of a river behave hydrologically similar, although the relation between discharge and area size depends on the geomorphology, geology, and ground cover for each catchment area. 
In applying Eq. (6) to calculate $Q$ values for small tributaries, however, we lack ground-based discharge data that can be used for verification. For this reason, we derived an estimate using discharge data observed at Manicore station.

Specifically, Eq. (6) was modified as follows, assuming $m=1$ and using $Q_{0}(t)$ and $A_{0}(t)$ values for a specific reference point :

$Q(t)=\frac{Q_{0}(t)}{A_{0}(t)} A(t)$

We set the reference point at Manicore station (see Fig. 2) and used its catchment area size $A_{0}(t) \cong A_{0}=$ $1,126,700 \mathrm{~km}^{2}$. We used both daily and average daily discharge figures for $Q_{0}(t)$ shown in Table 1.

Fig. 5 plots discharge $Q_{i}(t)$ against catchment area size $A_{i}(t)$. Discharge seems roughly proportional to area size for both dry (lower left) and wet seasons (upper right) for any tributary system at any threshold level. This consistency indicates that it is indeed possible to estimate discharge using Eq. (7), an encouraging sign with regard to the viability of satellite-based estimations, although of course such estimations lack ground-based verification.

A more detailed examination of the graph reveals that discharge in very low-water seasons (plots near the origin) seems to be nearly zero for narrower streams (width $<50 \mathrm{~m}$, i.e., $T h=90$ and 95$)^{7}$. This probably means that very narrow channels in low ${ }^{-}$ water seasons contain mostly standing water. We do not observe significant differences between daily discharge and average monthly discharge at Manicore station during both high-water and lowwater seasons, but we do see a slight dip in daily discharge during the transition period from highwater to low-water seasons. The large downward deviation from a straight line observed at the highest $^{-}$water season for $T h=90$ is probably caused by the formation of additional branches of streams that direct water into forests as opposed to from forests to rivers.

${ }^{7}$ The deviation from the straight lines near the origin appears to be not random in Fig. 5 although the amount of fluctuations seems to be within experimental errors.
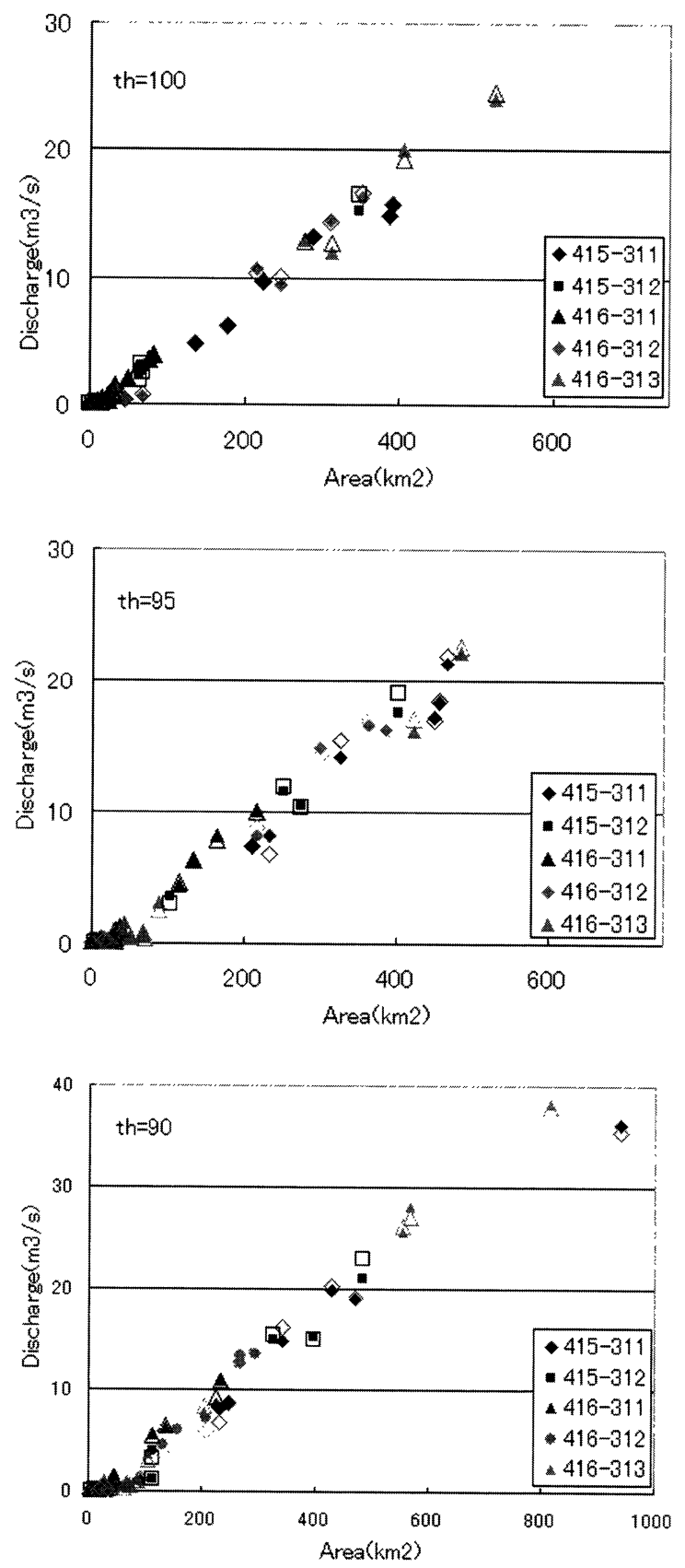

Fig. 5. Seasonal relationship between daily discharge (white markers)/average daily discharge (black or gray markers) and catchment area size of several small tributaries at each threshold level.

\section{Summary and conclusions}

We focused on double-bounce reflections along rivers in JERS-1 SAR images of the Amazon basin 
to develop a method that allows narrow streams in forested areas to appear as bright lines in satellite images reduced to $1 / 256$ size. The brightness of the visualized streams increased as their width and/or water level increased. When we examined the relationship between the total brightness of the rivers and their corresponding mainstream lengths for several tributary systems of the Madeira River, we found that total brightness was proportional to mainstream length, a hydrological parameter that can be used to calculate discharge. A mosaic of such images can be used as a practical quick-look water resource map because even very small such mosaics can cover a very wide area of land.

We also examined the seasonal relationship between catchment area size and discharge for several small tributary systems to explore possibilities for estimating discharge from satellite data. Under the assumption that the relationship among mainstream length, catchment area size, and discharge for a large river holds for its tributary systems, we estimated discharge for small tributaries from their mainstream length as well as discharge observed at a major downstream river. We found that all tributaries at any threshold level behave similarly and discharge was roughly proportional to catchment area size. Such a simple relationship seems quite encouraging for conducting satellitebased estimation of discharge in remote and dangerous tropical forests.

\section{Acknowledgment}

The authors wish to thank K. Nakasugi, T. Yoshioka, K. Ishida, and E. Ito, all undergraduate students at the Dept. of Applied Electronics, Science University of Tokyo, for helping us during the preliminary stages of this study. We also thank S. Dairaku of the Institute of Industrial Science, the University of Tokyo, for providing us with information about GPCC products.

(受付日2005.1.8, 受理日2005.9.9)

\section{References}

Hack, J.T., 1957. Studies of longitudinal stream profiles in Virginia and Maryland, U.S.G.S. Professional Paper, 294B, pp.445-497.

Hess, L.L., Melack, J.M. \& Simonett, D.S., 1990. Radar detection of flooding beneath the forest canopy : a review, Int. J. Remote Sensing, Vol. 11, No. 7, pp.1313-1325.

Hess, L.L., Melack, J.M., Filso, S., and Wang, Yong, 1995. Delineation of Inundated Area and Vegetation along the Amazon Floodplain with the SIRC Synthetic Aperture Radar, IEEE Trans. Geoscience and Remote Sensing, Vol. 33, No. 4, pp.896 -903 .

Inhoff, M.L., and Vermillion, C., Story, M.H., Choudhury, A.M., Gafoor, A., and Polcyn, F., 1987. Monsoon Flood Boundary Delineation and Damage Assessment Using Space Borne Imaging Radar and Landsat Data, Photogrammetric Engineering and Remote Sensing, Vol. 53, No. 4, pp.405 -413 .

Krohn, M.D., Milton, N.M., and Segal, D.B., 1983. Seasat Synthetic Aperture Radar (SAR) Response to Lowland Vegetation Types in Eastern Maryland and Virginia, J. Geophysical Research, Vol. 88, No. C3, pp.1937-1952.

Obmsby, J.P., Blanchard, B.J., 1985. Detection of Lowland Flooding Using Active Microwave Systems, Photogrammetric Engineering and Remote Sensing, Vol. 51, No. 3, pp.317-328.

Richards, J.A., Sun, G-Q, Simonett, D.S., 1987. LBand Radar Backscattering Modeling of Forest Stands, IEEE Trans. Geoscience and Remote Sensing, Vol. GE-25, No. 4.

Richards, J.A., Woodgate, P.W., and Skidmore, A. K., 1987. An explanation of enhanced radar backs cattering from flooded forests, Int. J. Remote Sensing, Vol. 8, No. 7, pp.1093-1100.

Rosenqvist, ̊., and Birkett, C.M., 2002a. Evaluation of JERS-1 SAR mosaics for hydrological applications in the Congo river basin, Int. J. Remote Sensing, Vol. 23, No. 7, pp.1283-1302.

Rosenqvist, Å., Forsberg, B.R., Pimentel, T., Rauste, 
Y.A., and Richey, J.E., 2002b. The use of spaceborne radar data to model inundation patterns and trace gas emission in the central Amazon floodplain, Int. J. Remote Sensing, Vol. 23, No. 7, pp. 1303-1328.

Sakurai-Amano, T., and Iisaka, J., 1999. Speckle Reduction of SAR images for Small Feature Extraction, J. Japan Soc. Photogrammetry and Remote Sensing, 38(3), pp.32-43.

Sakurai-Amano, T., Iisaka, J. and Takagi, M., 2004.
Semi-automated Detection of Narrow Rivers within the forested Areas of the Amazon Basin using JERS-1 SAR images, J. Japan Soc. Remote Sensing, Vol. 24, No. 3, pp.282-297.

Takahashi, Y., 1980. Kasen-Suimongaku (Hydrology in Japanese), Kyoritsu, $3^{\text {rd }}$ ed., Ch. 5.

Ulaby, F.T., Moor, R.K., \& Fung, A.K., 1986. Microwave Remote Sensing, Active and Passive, Arktech House, Inc., Vol. II, Ch. 7. 